\title{
PROCEEDINGS
}

OF THE

\section{NEW ENGLAND ZOÖLOGICAL CLUB}

\section{THIRTY-THREE NEW SPHINGIDAE}

BY BENJAMIN PRESTON CLARK

In describing these new forms of Sphingidae, bringing the total now described by me to one hundred, I wish again to acknowledge the help given me by scientists all over the world, who have made this possible.

My collection has now reached a total of twelve hundred and twenty-two species and subspecies, represented by some eightyfour hundred specimens. The total number of species and subspecies now known is, according to my records, thirteen hundred and fifty-four. I lack therefore one hundred and thirtytwo of the known forms, most of which are represented by one or two or three specimens, chiefly in public museums. While their rarity makes it increasingly difficult for me to acquire additional forms, the method of sending a photograph of the type specimen to a collector living near the locality where it was taken, has proved an effective one, and the very difficulties stimulate increased effort, for the scientific value of a complete collection of a family so widely dispersed throughout the world, as are the Sphingidae strongly appeals to men of science.

Rare and even type specimens have been given me, because it is known that my collection is not, in the ordinary sense of the term, a private collection. It is held by me simply in trust. 
When I leave it, it will go to some great Museum where it will be carefully preserved, and will be worked on and added to by some younger man of greater scientific attainments than my own. An effort in one tiny corner of the world of nature, in which I have been privileged to make a beginning, will be carried forward by others, to become, I hope and believe, of permanent value in advancing our knowledge of geologic history. I feel therefore no hesitation in asking for the best help from anyone who really cares for science, and I always find a ready and interested response. The brotherhood of those who love science is indeed a real and beautiful thing in the world, and to belong to it a privilege.

Meganoton analis subalba subsp. nov.

Al. ant. long., $\sigma^{\top}, 50 \mathrm{~mm}$; ᄋ , $60 \mathrm{~mm}$. Al. ant. lat., $\sigma^{\top}, 21 \mathrm{~mm}$; \% , $24 \mathrm{~mm}$. Marg. ext., $\sigma^{\top}, 29 \mathrm{~mm}$; ; , $33 \mathrm{~mm}$.

Habitat. - Kuangtung, southeastern China. A series of males and females, including the types, in coll. B. Preston Clark, received from Mr. Rudolf Mell. There are specimens also, from the same collector, at Tring and in the Berlin Museum.

This form is smaller than that from India. Its markings follow the typical form, but the fore wing above is more heavily irrorated with white, while the dark markings are black instead of the brown of analis. The wing has thus a more variegated look. There is more white also in the anal portion of the hind wing above, while the ground tone of the wing is darker than in analis. The chief difference beneath is that the cilia of both wings are more prominently white.

Protoparce scutata boliviana subsp. nov.

Al. ant. long., $\sigma^{\nearrow}, 44 \mathrm{~mm}$. Al. ant. lat., $\sigma^{\nearrow}, 17 \mathrm{~mm}$. Marg. ext., $\sigma^{\top}, 24$ $\mathrm{mm}$.

Habitat. - Bolivia. Two males in coll. B. Preston Clark, one from Warnes, received in exchange from the Carnegie Museum in 1919, the 
second received recently from Mr. A. Bang-Haas, with no more specific locality than Bolivia.

Dr. Karl Jordan, commenting on the first specimen, March 31, 1919, said "In structure the same as scutata, probably a subspecies or geographical form." Before describing it, I waited for another specimen. It seems certain that this form from Bolivia lies between the northern P. scutata R. and J. and $P$. scutata brasiliensis R. and J. from Rio de Janeiro. It is smaller than either of them, and much lighter in color throughout.

First segment of palpus lighter in tone than in the other subspecies, as is the thorax.

Fore wing above: Ground tone light gray; postmedian band, formed by the dark slaty sericeous patches, much narrower than in the other forms of this species. Wing less washed with brown and with white, giving a more uniform appearance.

Fore wing beneath: Lighter in color, with three strongly marked postmedian bands and a broad marginal band.

Hind wing above: White submarginal band closer to wing margin than in $P$. scutata, as close as in P. scutata brasiliensis. This band is less obscured by gray than in P. scutata brasiliensis.

Hind wing beneath: Postmedian band narrower and heavier than in either of the other forms.

\section{Sphinx tricolor sp. nov.}

Al. ant. long., $\sigma^{\top}, 44 \mathrm{~mm}$. Al. ant. lat., $\sigma^{7}, 17 \mathrm{~mm}$. Marg. ext., $\sigma^{\top}$, $23 \mathrm{~mm}$.

Habitat. - Dominican Republic. 700 metres altitude. One male (the type) in coll. B. Preston Clark, collected by Mr. Emil Kaempfer, August $22,1922$.

This specimen is, I believe, the first representative of the genus Sphinx to be taken in the West Indies. It belongs to the merops-justiciae group, but is shorter- and blunter-winged. Its name has been given because of the brick-red subbasal area of the fore wing above and the blue and white markings of the body and wings. 
Antennae brown above, white beneath. Palpi white, heavily irrorated with brown. Head and thorax gray. Mesothoracic tegulae gray, heavily bordered with black. Patagia white, irrorated with brown.

Abdomen above: A mesial yellow stripe, slightly interrupted at the segments by slaty blue transverse stripes, which latter are prominent laterally. Abdominal tergites black between the slaty blue stripes. Breast and legs white, heavily irrorated with brown. Abdomen beneath, yellow, lightly irrorated with brown.

Fore wing above: Of an unusual shape. The costal margin and the distal margin at the wing tip form an exact right angle. Distal margin is straight to R3; from this point it curves gradually and evenly, so there is no hinder angle at all. Wing as a whole gray, with prominent black and white markings. A lighter-colored insect than either S. merops Boisd. or S. justiciae Wlk. A prominent subbasal, longitudinal, brick-red area, $7 \mathrm{~mm}$. in length and $3 \mathrm{~mm}$. in width, similar to that of $S$. justiciae, but shorter. Double stigma, as in merops and justiciae, but in this form white edged with black. The markings are very like those of merops and justiciae, but there is no distal marginal band, its place being taken by three broad black lines, edged distally with white, lying between R3 and M1, M1 and M2, and M2 and SM2.

Hind wing above: Basal area and median band are slaty blue, similar in area and in width to those of $S$. justiciae, but partially interrupted at the veins, as in $S$. merops.

Fore wing beneath: Gray, irrorated with slaty blue. A broad wellmarked submarginal band, strongly convex distad. Basad of this band a distinct geminate interrupted line, with a third line following these two faintly, and parallel to them basally.

Hind wing beneath: Close to $S$. justiciae, but submarginal band brighter white.

\section{Amplypterus globifer Dyar}

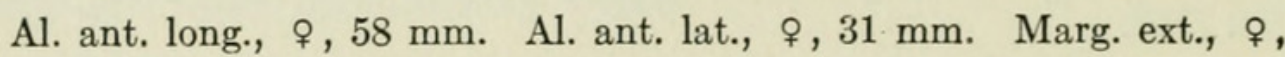
$22 \mathrm{~mm}$.

Habitat. - Zacualpan, Mexico. One female in coll. B. Preston Clark, presented to me by my friend Mr. Roberto Muller, of Mexico City.

The female of this rare species, not hitherto described, while following the general coloration of the male, is much lighter in tone. 
Fore wing above: Basal half with no markings whatever, save the subbasal patch with its base on inner margin. This patch is but $3 \mathrm{~mm}$. broad, while in the male it is $7 \mathrm{~mm}$. at its widest point. Apical half of the wing darker in tone than basal half, but much lighter than in male, and decidedly more uniform in color. Other markings faint.

Hind wing above: Light rose color, except for the following. One heavy brown submarginal patch, extending from anal angle to a point midway between M2 and M1. Two narrow distinct lines basad of this patch, and roughly parallel to it, the anterior one becoming obscure before reaching M2.

Fore wing beneath: Similar to male, but all markings faint. Red basal area lighter in tone and less extended.

Hind wing beneath: Lighter in tone than in male, and the transverse lines faint.

\section{Orecta acuminata sp. nov.}

\section{$21 \mathrm{~mm}$.}

Al. ant. long., $\sigma^{\top}, 37 \mathrm{~mm}$. Al. ant. lat., $\sigma^{\top}, 14 \mathrm{~mm}$. Marg. ext., $\sigma^{7}$,

Habitat. - One male in coll. B. Preston Clark, taken at Cerro de la Capa Vieja, near Tucuman, Argentina, altitude 1500-1800 metres, January 4, 1921, by Rodolfo Schreiter.

Antennae light brown; palpi, thorax, and abdomen above, light buff. Mesothoracic tegulae rich reddish brown. Median abdominal line faint, as are the transverse lines at the segments of the abdominal tergites. Legs and abdomen beneath light buff.

Fore wing above: Cilia dark brown. No basal dot. Light brown subbasal area, $2 \mathrm{~mm}$. in width and $4 \mathrm{~mm}$. in length, extends obliquely from a point on inner margin $3 \mathrm{~mm}$. distant from base toward a point on the costal margin one fourth the distance from base to apex. Prominent dark brown stigma at apex of cell, half within and half without it, $2 \mathrm{~mm}$. in diameter. Three more faint dots between this stigma and wing apex one between SC4 and SC5, $10 \mathrm{~mm}$. from apex, a second between SC5 and $\mathrm{R} 1,11 \mathrm{~mm}$. from distal margin between the veins, and a third between $\mathrm{R} 1$ and $\mathrm{R} 2,11 \mathrm{~mm}$. distant from distal margin between the veins. A sharply defined distal marginal band, similar to that in the genus Oxyambulyx, widens evenly from the wing tip until on $\mathrm{R} 2$ it is $2.5 \mathrm{~mm}$. broad; thence it narrows gradually to hinder angle. A dark streak $4 \mathrm{~mm}$. in length runs longitudinally between M2 and SM2 near hinder angle. No other markings on wing.

Hind wing above: Cilia dark brown, tipped with white. Wing unicolorous, save for a minute anal dot and a dark transverse mark $3 \mathrm{~mm}$. in length near anal angle. 
Fore wing beneath: Light yellow, unicolorous, except for a dot at apex of cell, the replica of that on upper side. Faint replicas also of the three other dots, and of the streak near hinder angle. Distal marginal band light gray, distinct.

Hind wing beneath: Light yellow, unicolorous, except for a shadow of the anal dot and anal band of the upper side.

An interesting form.

\section{Batocnema africanus Distant}

Al. ant. long., ㅇ, $43 \mathrm{~mm}$. Al. ant. lat., $\odot, 17 \mathrm{~mm}$. Marg. ext., , $23 \mathrm{~mm}$.

Habitat. - Central Africa. One female in coll. Mr. J. J. Joicey.

The female, which, so far as I know, has not been described, reproduces exactly the markings and coloration of the male, except that the under side of both wings is of a darker green tone.

Oxyambulyx sericeipennis f. aest. brunnea forma nova

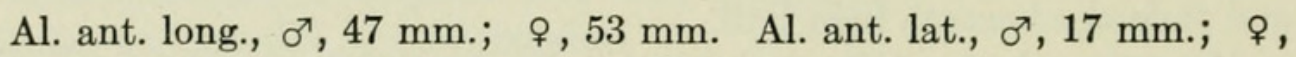
$20 \mathrm{~mm}$. Marg. ext., $\sigma^{\top}, 28 \mathrm{~mm}$; क \& $32 \mathrm{~mm}$.

Habitat. - Southeastern China. The types, and a series of males and females in coll. B. Preston Clark, received from Mr. Rudolf Mell. Specimens from the same collector also are at Tring and in the Berlin Museum.

Fore wing above: Ground color sayal-brown (not ash-gray with reddish suffusion, as in the spring). Entire wing more uniform in color, with markings less prominent than in typical sericeipennis. This seems to be the chief difference, and is very marked. The subbasal and discal spots in general are smaller than in the typical form, and sometimes entirely lacking.

Oxyambulyx brooksi sp. nov.

Al. ant. long., $\sigma^{\nearrow}, 54 \mathrm{~mm}$. Al. ant. lat., $\sigma^{\nearrow}, 20 \mathrm{~mm}$. Marg. ext., $\sigma^{\nearrow}$, $30 \mathrm{~mm}$.

Habitat. - Two males from Lebong district, southwestern Sumatra, 
collected by my friend, Mr. C. J. Brooks, and named for him. One male from the western slopes of the Barisan Range, southwestern Sumatra, $2500 \mathrm{ft}$. altitude, October or November, 1921, taken by C. F. and J. Pratt.

This species is of the substrigilis group, with the dark area at base of the hind wing. In general appearance it is like $O$. maculifera Walker.

Median line of abdomen above strongly marked. Divisions between the abdominal tergites also strongly marked by transverse dark lines; these lines are broader on posterior segments. Anal tip dark.

Fore wing above: This presents a highly variegated appearance, the contrast between the dark lines and the light ground color being strongly marked. Subbasal dot is $3 \mathrm{~mm}$. in diameter. Subbasal half-moon on costal margin lacking. Spot at hinder angle as in $O$. maculifera. Distal margin as in $O$. maculifera, curving evenly from wing tip to hinder angle.

Hind wing above: Dark basal area strongly marked. Transverse black median band broad and heavy. Submarginal black line dentate between the veins. Subapical dot $2 \mathrm{~mm}$. in diameter. Dot near anal angle between submarginal line and wing margin 1 to $1.5 \mathrm{~mm}$. in diameter.

Fore wing beneath: Ground tone light yellow, with brown markings. Dot near hinder angle $3 \mathrm{~mm}$. in diameter. Border of distal marginal band farthest from edge of wing, heavy and black.

Hind wing beneath: Ground tone light yellow, No dark basal area. Median and submarginal lines and subapical dot prominent.

\section{Deilephila placida rosacea Roth.}

\footnotetext{
Al. ant. long., $\sigma^{\top}, 35 \mathrm{~mm}$. Al. ant. lat., $\sigma^{7}, 14 \mathrm{~mm}$. Marg. ext., ఠ, $19 \mathrm{~mm}$.

Habitat. - Lifu. One male in coll. B. Preston Clark, from the original collection of Mr. C. Maxwell Stuart. There are three males and four females at Tring.
}

Deilephila placida torenia was described by Druce as Daphnis torenia (Ent. Mo. Mag., XIX, p. 16, 1882, Fiji - coll. Druce). See also Waterhouse, Aid Ident. Ins., II, t. 126, f. 1, 1883. In 1894 Lord Rothschild described the form from Lifu as Daphnis torenia Druce, subsp. rosacea (Novitates Zoologicae, Vol. I, p. 85). Though in the 'Revision of the Sphingidae,' by Roths- 
child and Jordan, Lord Rothschild's rosacea was reduced to synonymy (p. 519), I believe it to be valid.

As I compare my one example of the Fiji form with that from Lifu, also but one example, the Lifu form is far lighter in general tone, justifying the name 'rosacea.' This is true of the fore and hind wings, above and beneath.

The dark triangular area which in the Fiji insect extends from the wing tip along the distal margin to R1, in the Lifu form continues faintly to R3. The wing tip of the fore wing in the Lifu form is more acuminate, and the distal margin more concavebetween the wing tip and $\mathrm{R} 2$.

Another marked difference between the Fiji and the Lifu forms is in the basal half of the fore wing beneath. In the Fiji insect it is black except along the costal margin. The Lifu form has no such black area, while the typical $D$. placida placida Walker has this basal area but slightly darkened.

Marumba dyras plana subsp. nov.

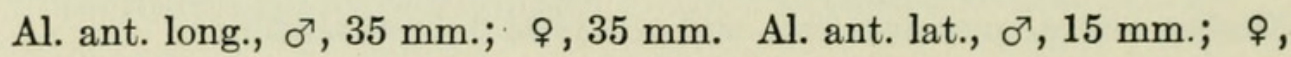
$15 \mathrm{~mm}$. Marg. ext., $\sigma^{\top}, 20 \mathrm{~mm}$.; ᄋ , $20 \mathrm{~mm}$.

Habitat. - Lo-tan-san, southeastern China. Two males and one female, including the types, in coll. B. Preston Clark; received from Mr. Rudolf Mell. There also are specimens at Tring and in the Berlin Museum.

This form is of the rainy season of the Plains. It is conspicuously pale, almost of the color of sand, between cartridge-buff and cream-buff, and pinkish buff up to chamois. The markings on the upper and lower sides of both wings are paler and smaller.

Isognathus zebra sp. nov.

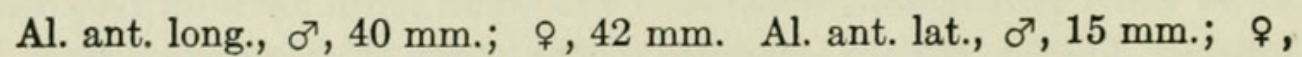
$17 \mathrm{~mm}$. Marg. ext., ơ , $21 \mathrm{~mm}$.; ᄋ , $22 \mathrm{~mm}$.

Habitat. - Para, Brazil. Two males and one female in coll. B. Preston 
Clark. A gift from my friend, Rev. A. Miles Moss, who reared them under great difficulties. He has specimens in his collection.

The remarkable larva of this species was described by Rev. A. Miles Moss (Novitates Zoologicae, XXVII, p. 378) and at that time was considered by him to be a subspecies of $I$. swainsoni Felder. It is quite clear, however, that this is not the case. Mr. Moss wrote me fully in September, 1922, and I quote in full all that he says, because he has done such distinguished work in the Sphingidae that his observations are of deep interest.

"I am now convinced that though most closely allied to swainsoni on the one side, and leachi on the other, and not far from excelsior as a third ally, it is a good species, and really specifically distinct from all three. Note these highly important differences, jotted down as they occur to my mind, and very fresh from some recent comparisons.

"1. The belted character and color of the larva of zebra is constant throughout, from egg to pupa, only that the head, plate, claspers and anus become increasingly bright orange vermilion, the black becomes more intensely velvety, and the white more purely white if possible (no trace of greenish or lemon-yellow anywhere, and no ochre as in the head and anus of swainsoni). The tail, from being considerably longer than the body in instar 2, becomes normal in length, as in leachi, in final instar; always dead black in final instar, very frail, easily broken, and eaten off by his fellow creatures. After moulting they all love to devour their old skins.

" 2 . Pure white belts in the larva of zebra reach right down to the red claspers. This is never so in either leachi or excelsior, but is so also in swainsoni. But note, these white belts in zebra are narrow and in middle of segment, thus giving twice as much black. The reverse holds good, I think, in swainsoni, and I never saw any red about the larva, so remarkable and striking a feature with zebra, shared by one form of excelsior to the last, and by leachi, but less flaming red, only to end of 4th instar, when a complete change of body pattern invariably takes place. 
"3. Note, excelsior has two forms of larva, my published form resembling leachi, but another, since found, resembling zebra, but the narrow belts on a black ground are always distinctly lemon-yellow, and do not reach the red claspers. The long black tail of excelsior is undoubtedly the longest of the whole genus, as yet known.

"4. My experience of the larva in the pattern, color, habits, and habitats, would seem to show that scyron and allamandae, also menechus and mossi, are further removed in the same genus from all four forms which I have mentioned. The resemblance in the moth of scyron is, I am convinced, superficial rather than real.

"5. The very select and fastidious habits of $z e b r a$, very rare in Para evidently, and only occasionally to be found on the tender-leaved Succubas growing in the heavy shade of giant forest trees, in itself indicates that it is a distinct species from I. swainsoni, which latter was always found by me in Perene and Chanchamayo on the Succubas growing in bush form on the hillsides in bright sunshine, surely an important consideration which can hardly be regarded as a subspecific feature.

"All this should be taken into account and remembered, whatever else may subsequently be determined by the examination of the various imagines and their genitalia. Be careful, therefore, in your descriptions to note that, from the larva zebra is near to tetrio, nearest to swainsoni, near to leachi, equally near to excelsior (generally an Amorpha feeder) but far from scyron (invariably and only on Allamanda). This genus Isognathus constitutes a highly important biological study."

Coming to a description of the adult insect, the relative emphasis which should be given to differences in the imagos of the Sphingidae, and to differences in the juvenal stages, is one of those things upon which much may be said. There is no doubt that in its general facies Isognathus zebra is closer to I. scyron Cr. than to any other form. As I compare my pair of I. zebra with a long series of $I$. scyron, differences are hard to detect.

The male of $I$. zebra has, basally of the dark postmedian longitudinal area between R3 and M1, three heavy dark lines, 
$2 \mathrm{~mm}$. in length, perpendicular to the costal margin, one outside and two inside the cell. In I. scyron these three are replaced by a dark semicircle, open costad. In no other respect does the male of $I$. zebra show any difference from $I$. scyron, either above or beneath.

The female of $I$. zebra is less irrorated with white on the veins of the fore wing above than is $I$. scyron, and has an irregularly roundish black blotch, $2 \mathrm{~mm}$. in diameter, at the apex of the cell, which is lacking in $I$. scyron.

The dark marginal band of the hind wing above is much broader than in $I$. scyron, being $8 \mathrm{~mm}$. wide between M2 and SM2 and $10 \mathrm{~mm}$. wide on inner margin. In $I$. scyron the width at these points is $5 \mathrm{~mm}$. and $7 \mathrm{~mm}$. The ground tone of both wings beneath is darker than in $I$. scyron.

Differenees between $I$. zebra and I. swainsoni and I. leachi are easier to detect. I. swainsoni has, both in the male and in the female, much more white on the fore wing above, giving it a variegated appearance. I. leachi has, both in the male and in the female, more light brown on the fore wing above, giving it also a variegated appearance. Both $I$. swainsoni and $I$. leach $i$ have a subbasal longitudinal patch, $7 \mathrm{~mm}$. in length, which $I$. zebra lacks.

The dark distal marginal band of the hind wing above of $I$. swainsoni, is broader in the male than in $I$. zebra, and fully as broad in the female. In $I$. leachi this band is slightly narrower in the male, and much narrower in the female.

It is my hope to make a full study of the genitalia of this genus, and especially of these closely allied forms.

\section{Polyptychus neavi Hampson (1910) and Polyptychus martha}

Closs (1911)

Lord Rothschild has said (Novitates Zoologicae, Vol. XXVI, p. 209) "We have come to the conclusion that neavi Hampson and martha Closs are synonyms of calcareus." 
I never have seen the type of $P$. neavi, but possess that of $P$. martha Closs, and I feel confident that the latter is distinct from $P$. calcareus, and that in all probability $P$. neavi and $P$. martha are the same species. The fuscous median band in the type of $P$. martha is entirely lacking in the three specimens in my collection of $P$. calcareus from Rhodesia. In addition, the thorax of each one of the three specimens of P. calcareus is unicolorous, while in the type of $P$. martha the mesothoracic tegulae are much darker than the median portion of the thorax, making a strong contrast. This same contrast is brought out in the colored drawing of P. neavi in P. Z. S. (1910), Plate XXXIX, no. 26.

\section{OBERTHURION gen. nov.}

This new genus is closely allied to Pachylia. Spines of distal tergites uniseriate, all long, very heavy. Eye large, not lashed. Antennae strongly clubbed, hook long and thick; end segment rather blunt. Distal margin of both fore and hind wings undulate between the veins, strongly so in the fore wing, less so in the hind wing. Costal margin curves strongly back toward wing apex, producing a wing of unusual form, with a breadth almost equal to the exterior margin. It is a privilege, as well as most fitting, to name this remarkable new genus, the first one discovered in the Sphingidae of the Western Hemisphere for more than twenty years, for my dear friend Mr. Charles Oberthur, who stands today preëminent among the entomologists of the world.

\section{Oberthurion harroverii sp. nov.}

Al. ant. long., $\sigma^{x}, 47 \mathrm{~mm}$. Al. ant. lat., $\sigma^{x}, 23 \mathrm{~mm}$. Marg. ext., $\sigma^{x}$, $25 \mathrm{~mm}$.

Habitat. - Valley of the Chirripo River, Costa Rica, $1500 \mathrm{ft}$. altitude. Taken on the trail in dense vegetation by Mr. David E. Harrower, July 21, 
1915, and acquired by me from him. It had been deposited by him temporarily in the Philadelphia Academy of Sciences, where my attention was called to it by my friend, Dr. Henry Skinner. One male (the type) in coll. B. Preston Clark.

Antennae brown above, white beneath. Palpi: first and second segments light brown, third segment dark brown. Legs wood-brown. Spines of tergites light brown at the tips. Head, thorax and abdomen above, dark brown. Abdomen wood-brown beneath.

Fore wing above: Wood-brown with darker markings. Costal margin curving backward strongly toward wing tip, producing an unusual wing form. Distal margin strongly undulate between the veins. Cilia dark brown. Dark brown subbasal spot $1.5 \mathrm{~mm}$. in diameter. Narrow subbasal line extends irregularly from a point on costal margin $9 \mathrm{~mm}$. distant from the base to a point on inner margin $8 \mathrm{~mm}$. distant from the base. Posteriorly of this line two geminate antemedian lines enclose an irregular dark brown band, 2 to $3 \mathrm{~mm}$. in width, extending from costal to inner margin. A prominent dark brown circular spot within the cell at its apex, $3.5 \mathrm{~mm}$. in diameter. An S-shaped postmedian line extends from a point on costal margin, $21 \mathrm{~mm}$. from wing apex in a direct line, to inner margin, which it reaches $12 \mathrm{~mm}$. from the hinder angle. This line is concave basad from costal margin to M1, thence convex basad to inner margin. Posteriorly of this line, extending from M1 to inner margin, is a prominent dark brown area $8 \mathrm{~mm}$. in width along M1 and between M1 and M2. Along M2 it broadens sharply $2.5 \mathrm{~mm}$. toward distal margin, and thence broadens again concavely to the hinder angle. It is $13 \mathrm{~mm}$. wide along inner margin. A second transverse postmedian line runs, roughly parallel to the first, from the costal margin to M1, where it is lost in the large dark brown patch. A third postmedian line extends from a point on costal margin, $16 \mathrm{~mm}$. distant from apex in a direct line, regularly concave basad to the corner of the large dark brown area, which it reaches on M1 at its exact corner. Between this third postmedian line, the wing apex and M1, is a dark brown area, its point just crossing M1. Within this area, extending along the costal margin $13 \mathrm{~mm}$, is a lighter, flatly triangular area, extending to SC5 at its basal limit, and thence narrowing to wing apex. Posteriorly of M2 the wing grows gradually lighter in color.

Fore wing beneath: Wood-brown. Cilia dark brown. A light streak along inner margin. A heavy dark brown postmedian transverse line duplicates the first postmedian line of the upper side; a second thinner postmedian line, slightly undulate between the veins, duplicates the third postmedian line of the upper side, but extends the entire distance to the inner margin, which it reaches $5 \mathrm{~mm}$. from hinder angle. Distally of this line a dark triangle with its base, $8 \mathrm{~mm}$. wide, on costal margin, has its point a trifle beyond R1. Distal margin undulate between the veins.

Hind wing above: Cilia brown, tipped with white, prominently so 
toward anal angle. Dark brown distal marginal band, $9 \mathrm{~mm}$. in width along inner margin, narrows gradually to hinder angle, where it is $3 \mathrm{~mm}$. in width. This band is gently convex basad. Parallel to this band, and basad from it, is a narrow dark brown line, about $1 \mathrm{~mm}$. distant from the band. The remainder of the wing is wood-brown, with a faint transverse median shade which fades away before reaching inner margin.

Hind wing beneath: Cilia brown, tipped with white, more conspicuously so than on upper side. Entire wing wood-brown, crossed by two transverse lines; one median, slightly convex basad, the other submarginal, undulate between the veins, and following the line of the edge of the distal marginal band on upper side of the wing. It is thus $9 \mathrm{~mm}$. distant from wing tip on inner margin, and $3 \mathrm{~mm}$. distant from hinder angle at that point.

A beautiful and distinguished-looking insect.

Panacra niasana sp. nov.

Al. ant. long., $\odot, 23 \mathrm{~mm}$. Al. ant. lat., $+9 \mathrm{~mm}$. Marg. ext., $12 \mathrm{~mm}$.

Habitat. - North Nias, near Sumatra. One female (the type) in coll. B. Preston Clark, received in exchange from my friend, Dr. Karl Jordan.

This form is so close to P. malayana R. and J. as to be easily confounded with it. It is, however, clearly distinct.

Fore wing above: The entire ground tone is darker than in P. malayana, giving the appearance of greater uniformity of tint. First discal line does not reach costal margin. This line is more nearly parallel to the costal margin than in $P$. malayana, being $4 \mathrm{~mm}$. distant from it on the inner margin, and $2 \mathrm{~mm}$. distant where it fades away toward the wing apex. This line in $P$. malayana is $5 \mathrm{~mm}$. distant from the costal margin on the inner margin, and actually reaches this margin apically. White sagittate marking between SC5 and R1 is more acute in this form than in P. malayana. Postdiscal lines are more distinct and more closely parallel.

Hind wing above: Light submarginal area is less marked, entire wing darker.

Fore wing beneath: Reddish brown postmedian area is darker in tone, but less irrorated with black.

Hind wing beneath: Darker in tone. White antemedian dot more prominent. 


\section{Cizara schausi sp. nov.}

Al. ant. long., $\sigma^{\Upsilon}, 24 \mathrm{~mm}$. Al. ant. lat., $\sigma^{\top}, 10 \mathrm{~mm}$. Marg. ext., $\sigma^{\top}$, $13 \mathrm{~mm}$.

Habitat. - Unknown. Two males in coll. B. Preston Clark (one the type), received in exchange from the American Museum of Natural History, New York, and originally from the collection of my friend Dr. William Schaus.

This insect is so closely allied to Cizara sculpta Felder that its specific difference for a long time escaped me.

Head, thorax and abdomen above uniformly olive green. The broad median thoracic pink stripe and the prominent thoracic side stripes of $C$. sculpta are lacking.

Fore wing above: The marginal costal line, extending prominently in C. sculpta from the wing base to the transverse postmedian line, is lacking. Light-colored subbasal area is less prominent. Transverse postmedian line is costally farther removed from the widest point of the light-colored distal marginal band between $\mathrm{R} 1$ and $\mathrm{R} 2$, being at that point 3 to $4 \mathrm{~mm}$. distant from it; while in C. sculpta it is but $1 \mathrm{~mm}$. to $2.5 \mathrm{~mm}$. distant. Light-colored band along inner margin is narrower than in C. sculpta.

Fore wing beneath: Much darker in tone than in C. sculpta, distal marginal band especially so. A prominent red line roughly follows the course of anterior edge of distal marginal band on upper side of wing.

Hind wing above: Markings at anal angle less prominent than in $C$. sculpta.

Hind wing beneath: More heavily irrorated with red than in C. sculpta; distal marginal band darker in tone.

Clasper of same shape as in C. sculpta, harpe more elongate, terminating basad in a sharp point, instead of with the bluntness of $C$. sculpta. Penis sheath more elongate than in $C$. sculpta.

In other respects this insect follows the color and markings of Cizara sculpta Felder.

Nephele accentifera comoroana subsp. nov.

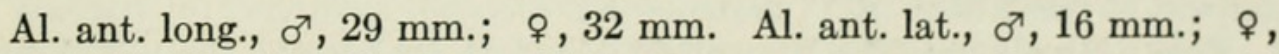
$13 \mathrm{~mm}$. Marg. ext., ơ $16 \mathrm{~mm}$.; ᄋ , $17 \mathrm{~mm}$.

Habitat. - Grande Comoro Island. A series of males and females in 
coll. B. Preston Clark, collected by Mr. George F. Leigh, September to December, 1921.

This is a smaller and shorter-winged insect than the typical form. The chief differences are observed in the upper side of the fore wing.

Fore wing above: There is less contrast between the dark and light portions of the wing than in $N$. accentifera Beauvois, and less yellow irroration. In $N$. accentifera the area between the geminate subbasal line of the fore wing and the irregular geminate median line, is variegated. In $N$. accentifera comoroana the entire area between the anterior subbasal line and the posterior median line is uniformly dark brown, save for the silvery markings and a light brown semilunar area on the costal margin.

The light-colored postmedian band, which in $N$. accentifera is irregular and much obscured mesially, in this form extends evenly from costal to inner margin, with no mesial break.

\section{Temnora camerounensis sp. nov.}

Al. ant. long., ㅇ, $20 \mathrm{~mm}$. Al. ant. lat.,,$+ 8 \mathrm{~mm}$. Marg. ext., ㅇ, $11 \mathrm{~mm}$.

Habitat. - Cameroun. One female in coll. B. Preston Clark, received from Mr. J. J. Joicey, without exact statement of locality.

This species is near T. rattrayi $R$. and J. Dr. Karl Jordan, to whom I sent the specimen for his judgment, says "close to rattrayi, but the markings not exactly the same." As the tip of the abdomen is lacking, it is not possible to say surely whether this is a subspecies of $T$. rattrayi or not. My belief is that it is a distinct form. It is most easily described by comparison with T. rattrayi.

The fore wing is narrower. The length of the fore wing of a female of $T$. rattrayi used in comparison is $20 \mathrm{~mm}$., and the exterior margin $11 \mathrm{~mm}$., the same as in T. camerounensis. The width of the fore wing is $9 \mathrm{~mm}$., instead of the $8 \mathrm{~mm}$. of $T$. camerounensis.

Fore wing above: The brown triangle, with its base on the costal margin, has in T. rattrayi the side toward the wing apex perpendicular to the 
costal margin, and is thus scalene. In T. camerounensis the apical side is angled acutely to the costal margin, the triangle being equilateral. The contrast in color between this triangle and the basal area is greater than in T. rattrayi, the triangle being of a darker brown and the ground tone of the wing lighter. In $T$. rattrayi there are two bands, one subbasal, one median, both curving basad as they approach the costal and the inner margin. In $T$. camerounensis the areas included in these two bands are faintly indicated by interrupted geminate lines. The narrow white line bordering the costal marginal triangle in $T$. rattrayi apically, is in this form a brighter white, and broadens costally. A dark line extends from a point on the costal margin, $4 \mathrm{~mm}$. distant from the wing tip, and at right angles to it, to SC5; thence it extends basad to a point between R1 and R2, where it curves distad to R2; thence first basad and then distad to R3, where it merges into the dark line which this form has in common with T. rattrayi.

Fore wing beneath: Otherwise like T. rattrayi, it has on the costal margin, 5.5 and $4 \mathrm{~mm}$. distant from the wing tip, two bright white dots, one $\mathrm{mm}$. in diameter, which are only obscurely indicated in T. rattrayi.

Hind wing above: Dark brown, unicolorous except for a light brown area at anal angle, crossed by a narrow, dark submarginal line.

Hind wing beneath: Like T. rattrayi, except for a pink line extending from base to apex near anal angle.

\section{Temnora rattrayi $\mathrm{R}$. and $\mathrm{J}$.}

Al. ant. long., ㅇ, $19 \mathrm{~mm}$. Al. ant. lat., ᄋ , $8 \mathrm{~mm}$. Marg. ext., ค, $10 \mathrm{~mm}$. Habitat. - Banga Manteke, Belgian Congo. One female in coll. B. Preston Clark, collected by Mr. A. L. Bain, and received in exchange from Dr. W. J. Holland of the Carnegie Museum. The female of this species, so far as I know, has not been previously noted.

The female of this rare species, at least in this instance, follows the pattern of the male, but the markings are more indistinct.

\section{Gurelca mulleri sp. nov.}

Al. ant. long., $\sigma^{7}, 21 \mathrm{~mm}$. Al. ant. lat., $\sigma^{7}, 7 \mathrm{~mm}$. Marg. ext., $\sigma^{7}, 8 \mathrm{~mm}$. Habitat. - Guerrero, Mexico. One male in coll. B. Preston Clark, presented by my friend Mr. Roberto Muller, of Mexico City, for whom I have named it. 
This is the second Mexican form of this genus, that I have described, and their discovery suggests the possibility that representatives of this genus may be found farther south, in the mountains of Central America and among the Andes.

Antennae gray above, brown beneath. Palpi gray irrorated with brown. Thorax and abdomen above, gray irrorated with brown. Legs gray. Abdomen beneath gray irrorated with brown. Sternites 4, 5 and 6 , dark red irrorated with yellow. A minute white lateral dot on each side of the three segments. Cilia black, prominently white between the veins above and beneath.

Fore wing above: Bluish gray with darker markings. While this color differs markedly from that of $G$. sonorensis Clark, the pattern of the wing in the two is almost identical, as is the outline of the distal margin. The contrast in color between the light and dark portions of the wing is greater than in G. sonorensis, and the markings are more distinct in character. The stigma is half-moon-shaped and very narrow, convex basad. In this form there is a prominent dark sagittate area, median on the wing, with its bases on the costal margin rather more than half way to the apex, and on the median portion of the inner margin. The point of this sagittate area is on R3.

Fore wing beneath: Gray irrorated with red, the irrorations becoming heavy toward discal margin. Irregular marginal discal band, bluish gray, $3 \mathrm{~mm}$. in width. Stigma present, but straight and less prominent.

Hind wing above: Bright yellow with black discal marginal band, which is narrower than in G. sonorensis; it is even in width and clearly marked, as in $G$. hyas Walker. This band contains within it at anal angle a bluish gray patch enclosing a black line parallel to discal margin.

Hind wing beneath: Bluish gray along inner margin. Distal marginal band also bluish gray, narrow at anal angle and broadening to inner margin. Rest of wing area yellow. A bright yellow band along the anal margin; remaining area heavily irrorated with red, and crossed by four red bands from SM2 to M1, where they become obscure.

Antinephele weberi sp. nov.

Al. ant. long., $\sigma^{\top}, 17 \mathrm{~mm}$. Al. ant. lat., $\sigma^{\top}, 8 \mathrm{~mm}$. Marg. ext., $\sigma^{\top}, 10 \mathrm{~mm}$. Habitat. - Efulan, Cameroun. One male in coll. B. Preston Clark, collected by Dr. H. L. Weber, and received in exchange from Dr. W. J. Holland. 
This is the smallest and one of the loveliest of the Antinepheles, and I take pleasure in naming it after my friend Dr. H. L. Weber, who has done such distinguished work in collecting lepidoptera in the Cameroun country. It lies between $A$. muscosa Holl. and A. lunulata R. and J., and is closer to the latter.

Antennae brown. Palpi white irrorated with brown, shading to olive green on second and third segments, darkest at tips. Thorax and abdomen above olive-greenish brown. Thorax crested, crest tipped with white. Mesothoracic tegulae tipped prominently with yellow. Legs yellow. Abdomen beneath white, irrorated heavily on posterior sternites with light yellow and dark red.

Fore wing above: Olive-greenish brown. Distal margin strongly convex. As in $A$. lunulata, no distinct bands. Lines not lunulate as in $A$. lunulata, but in the main straight and roughly at right angles to costal margin. Black basal dot; also black basal area close to inner margin. Prominent black stigma between R1 and R2, posteriorly of apex of cell. Small brown apical half-moon, followed by an elongate triangular marginal patch, pointed behind, proximately bordered by a white line, all as in $A$. lunulata. The triangle, however, is narrower at the base, being but $1 \mathrm{~mm}$. wide, as compared with a width of fully $2 \mathrm{~mm}$. in A. lunulata. The white line is more prominent, and straighter. Area between stigma and discal triangle is lighter in tone than the remainder of the wing.

Fore wing beneath: Basal area black, olive green along costal margin. A light yellow area, roughly rectangular in shape, extends from a point on costal margin, $4 \mathrm{~mm}$. from wing apex, to R3, thence to the narrow black distal marginal band, less than $1 \mathrm{~mm}$. broad, which it reaches at M1. From this point it follows the marginal band to the costal margin near wing tip. This yellow area contains one distinct lunulate line, the lunules being convex distally. Basad of this line, within the area, is another lunulate line, faint in character. Distad of the distinct line is a third one, distinct, sagittate between the veins, the segments pointing basad between the veins.

Hind wing above: Black, unicolorous.

Hind wing beneath: Divided into two areas. The first is light yellow, extending from R3 on the distal margin to the wing base, and including the entire area between this line and the inner margin. The second area is black, and includes the anal half of the wing, except where it is light yellow along the extreme anal edge. The wing is crossed by five transverse lines; the three anterior ones traverse the entire wing, while the two posterior ones become obscure at R3. 
Sphecodina caudata angulilimbata subsp. nov.

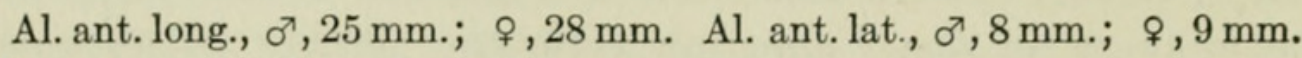
Marg. ext., $\sigma^{7}, 13 \mathrm{~mm}$; ; , $15 \mathrm{~mm}$.

Habitat. - Southeastern China. A series of males and of females, including the types, in coll. B. Preston Clark, received from Mr. Rudolf Mell.

The chief difference between this race and typical caudata is in the hind wing above. The yellow is fainter, a pale orange, distally somewhat transparent. The black distal border is distinctly narrower, above and beneath.

Macroglossum semifasciata nigellum R. and J.

Al. ant. long., $~$, $25 \mathrm{~mm}$. Al. ant. lat., $\odot, 10 \mathrm{~mm}$. Marg. ext., + , $14 \mathrm{~mm}$.

Habitat. - Woodlark Island, Papua. One female in coll. B. Preston Clark, received from Mr. H. P. Schrader, Carlton, New South Wales.

The male of this species was described in Novitates Zoologicae, Vol. XXIII, p. 122, but, so far as I know, the female has remained undescribed. It is similar to the male, but the vein streaks connecting the brownish black basal area of the hind wing with the distal border are faint, and on a number of the veins entirely lacking. This gives the impression of a more continuous yellow band on the hind wing. In this particular it follows $M$. glaucoptera, in which the band on the hind wing is much less interrupted and broader in the female than in the male.

\section{Xylophanes juanita R. and J.}

Al. ant. long.,, $32 \mathrm{~mm}$. Al. ant. lat.,,$+ 12 \mathrm{~mm}$. Marg. ext., $18 \mathrm{~mm}$.

Habitat. - San Pedro Sula, Honduras. One female in coll. B. Preston Clark, collected by H. Fruhstorfer. 
The female of this species, so far as I know, has not been described. In all respects it resembles the male in its facies and markings, and I include it here chiefly because of this fact. In other members of this family differences are to be seen between specimens from Mexico, whence the male of $X$. juanita was first described, and those from Central America.

\section{Xylophanes schreiteri sp. nov.}

Al. ant. long., $\sigma^{\nearrow}, 37 \mathrm{~mm}$; $~$, $37 \mathrm{~mm}$. Al. ant. lat., $\sigma^{\Upsilon 7}, 12 \mathrm{~mm}$; , $12.5 \mathrm{~mm}$. Marg. ext., ठ, $20 \mathrm{~mm}$.; \&, $19 \mathrm{~mm}$.

Habitat. - Tucuman, Argentina. A series of males and one female in coll. B. Preston Clark, collected by Mr. Rodolfo Schreiter.

This species is close to Xylophanes crotonis zikani Clark, but is in general a darker-colored insect.

The antennae, thorax, and abdomen above are all a darker green than in $X$. crotonis zikani.

Fore wing above: The wing tip is more projected than in zikani. The space between lines 1 and 2 is filled in darkly. This space, as well as the area between it and the costal margin, is darker than in zikani, and darker than the rest of the wing. These two lines and their enclosed area are somewhat wavy. These lines, as also lines 3 to 7 inclusive, are curved more sharply distad as they approach the wing apex than in zikani. The yellow basal tuft is smaller.

Fore wing beneath: The pattern is almost identical with that of $X$. nabuchodonosor, but the postmedian lines and bars, which in that species are black, are in $X$. schreiteri rusty red, the entire wing surface being heavily irrorated with this color and with black.

Hind wing above: Identical with $X$. crotonis zikani.

Hind wing beneath: Close to $X$. nabuchodonosor, but the ground tone is a rustier red than in that species, and the distal marginal band is narrower.

Theretra cajus ugandae subsp. nov.

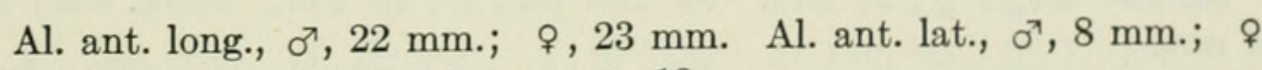
$8.5 \mathrm{~mm}$. Marg. ext., ఠ઼, $12 \mathrm{~mm}$; † , $13 \mathrm{~mm}$.

Habitat. - Kibwezi, Kenia Colony. One male and one female in coll. B. Preston Clark, collected by Mr. R. A. Dummer, December, 1921. 
This East African form of $T$. cajus Cr. differs markedly both from it and from T. cajus perkeo R. and J. Its general facies is fairly close to T. cajus, while in size it approximates closely to T. cajus perkeo.

Antennae, thorax, and abdomen above and beneath dark brown, shading to black, the silvery markings dull in tone.

Fore wing above and beneath: Ground tone dark brown, shading to black. Silvery markings similar to those of $T$. cajus, but duller in tone.

Hind wing above: Uniformly black, save for a faint submarginal band extending from anal angle to R3, where it becomes obscure.

Hind wing beneath: Dark brown; bands darker in tone than in the other forms.

Hippotion noel sp. nov.

Al. ant. long., ఠ $\sigma^{7}, 27 \mathrm{~mm}$; $ণ, 34 \mathrm{~mm}$. Al. ant. lat., $\sigma^{\top}, 10.5 \mathrm{~mm}$; ণ , $12.5 \mathrm{~mm}$. Marg. ext., ơ $14 \mathrm{~mm}$; ㅇ , $18 \mathrm{~mm}$.

Habitat. - Christmas Island. One male and one female (types) in coll. J. J. Joicey, at the Hill Museum. Cotypes in coll. B. Preston Clark. All collected by C. W. Andrews in September and October, 1897.

This form has the facies of $H$. velox Fabr. It lacks, however, the silvery lines and markings of the fore wing above and of the abdomen above. It has the more uniform coloration of $H$. beddoesii Clark, but lacking the darker markings of that form, is a more unicolorous insect. All the specimens of this form are so uniform in their characters, and differ so widely from typical $H$. velox, that it seems to deserve specific separation.

\section{Hippotion lambertoni sp. nov.}

Al. ant. long., $\sigma^{\top}, 27 \mathrm{~mm}$. Al. ant. lat., $\sigma^{\top}, 12 \mathrm{~mm}$. Marg. ext., $\sigma^{\top}$, $11 \mathrm{~mm}$.

Habitat. - Farafangana, southeastern Madagascar. One male in coll. B. Preston Clark, collected by Mr. C. Lamberton. 
This species belongs to the balsaminae-saclavorum-batschi group, falling between the first species and the other two.

Palpi olive green, shading to gray on third segment. Antennae olive green, white toward tip, and black at extreme apex. Head, thorax and abdomen above, olive green. Light-colored side stripe extending from above the eye laterally along the thorax. Mesothoracic tegulae reddish brown. Abdomen beneath clay-color irrorated with brown, and shading to light red laterally. Legs clay-color irrorated with brown.

Fore wing above: Light olive green with dark olive green markings. Wing apex sharply acuminate and black. From the wing apex to the inner margin, which is reached at its median point, extends a dark heavy olive green line, curving first slightly basad and then distad. Basad of this heavy line, which may be called no. 4, extend three parallel lines, nos. 1, 2 and 3, lighter in tone than no. 4, and fading away costally. Distally of line no. 4 there extends from apex to innér margin line no. 5 , heavy and dark olive, the space between lines 4 and 5 being filled in with the same dark olive tone. Midway between line 5 and the distal margin extends faintly line 6 . Line 7 is faint and submarginal. There is a minute black stigma with a dark cloud apically of it. Distal margin markedly convex.

Fore wing beneath: Ground tone light brick-red. Basal half black, except along the costal margin, where it is olive green. From this black area there extend three interrupted black lines. The basal one reaches the costal margin $10 \mathrm{~mm}$. from the wing apex, the median one reaches this margin $6 \mathrm{~mm}$. from the apex, while the apical one terminates at the apex. The two proximal lines are interrupted on the veins, the distal one between the veins. A distal marginal band, lighter in tone than the rest of the wing, broadens to a point between R2 and R3, where it attains a width of $6 \mathrm{~mm}$., thence it narrows to the hinder angle.

Hind wing above: Black with narrow and somewhat interrupted postmedian light pink band, broadening anally.

Hind wing beneath: Light red. Two clay-colored median bands, curving basad and separating as they approach the costal margin. A claycolored distal marginal band broadens to a point between R2 and R3, where it is $3 \mathrm{~mm}$. in width, thence it narrows anally.

\section{Rhagastis mjobergi sp. nov.}

Al. ant. long., $\sigma^{\top}, 26 \mathrm{~mm}$; $\odot, 27 \mathrm{~mm}$. Al. ant. lat., $\sigma^{\top}, 11 \mathrm{~mm}$; ; , $12 \mathrm{~mm}$. Marg. ext., $\sigma^{\top}, 13 \mathrm{~mm}$; ๆ , $15.5 \mathrm{~mm}$.

Habitat. - Siantar, Sumatra. One male (the type) in coll. B. Preston 
Clark, received from my friend, Dr. Eric Mjoberg, and named for him. One female from Hainan, from the collection of Geheimrat A. Huwe.

Dr. Karl Jordan says of this form, which he was kind enough to examine at my request, "between acuta and rubetra."

Third segment of palpus triangular, as in $R$. acuta Walker, and $R$. rubetra $\mathrm{R}$. and $\mathrm{J}$. Centre of head and thorax, and markings of upper side of fore wing, nearly as dark as in $R$. rubetra. Under side of wings and sides of breast ferruginous as in $R$. rubetra; less irrorated with black than in $R$. acuta. Under side of abdomen faintly pink.

Fore wing above: Similar to $R$. acuta. Distal margin more convex toward wing apex. Markings faint, except for a dark submarginal area like that of $R$. rubetra, between $\mathrm{R} 1$ and $\mathrm{R} 3$, and $3 \mathrm{~mm}$. distant from distal margin. The three subbasal lines of $R$. rubetra are lacking. The posterior half of the wing is lighter in color than in $R$. acuta, this being especially marked in the male. Hind wing above, similar to $R$. acuta.

The five following new forms were taken by Messrs. C. F. and J. Pratt in southwestern Sumatra during the summer of 1921, and were given to me by my friend, Mr. J. J. Joicey. They are of unusual interest.

\section{Oxyambulyx joiceyi sp. nov.}

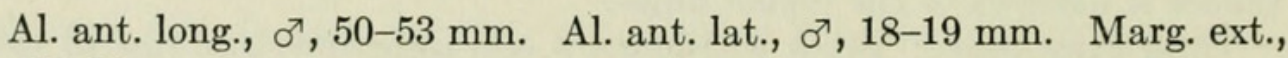
$\sigma^{7}$, 29-31 mm.

Habitat. - Southwestern Sumatra, July-September, 1921. C. F. and J. Pratt. Two males in coll. B. Preston Clark, one taken on the slopes of Mt. Korintji, $7300 \mathrm{ft}$., August-September. The other taken in North Korintji Valley, $5000 \mathrm{ft}$., September-October. The former is the type. There are other specimens in the Hill Museum, Witley, Surrey, England.

In general appearance this species is closer to Oxyambulyx placida Moore than to any other of the genus. It is darker in general tone.

Abdominal mesial line distinct; mesial patch on eighth tergite; two side dots on sixth tergite. 
Fore wing above: Wing apex strongly produced. Subbasal semilunar costal spot beyond subbasal bar, $4 \mathrm{~mm}$. distant from wing base. The large subbasal round patch behind cell, prominent in $O$. placida, is lacking in the first specimen, and vestigial in the second. Distal marginal band widens evenly from apex to R2, where it is $3.5 \mathrm{~mm}$. wide; thence it narrows evenly to the hinder angle. Black submarginal distal line continued to hinder margin, here $.5 \mathrm{~mm}$. from edge of wing. A light line runs parallel to the dark one, basad of it, as in O. placida. Veins dark postmesially, especially SC5, R1 and R3.

Fore wing beneath: Distal marginal band evenly curved, as on upper side. Black submarginal line prominent, and in the second specimen (that from $5000 \mathrm{ft}$.) there is much extended rufous over the posterior third of the wing.

Hind wing above not dark at the base.

Hind wing beneath. Anal area prominently gray from base to anal angle.

Marumba sperchius sumatranus subsp. nov.

\author{
Al. ant. long., ᄋ, $70 \mathrm{~mm}$. Al. ant. lat., $९, 25 \mathrm{~mm}$. Marg. ext., ㅇ, \\ $38 \mathrm{~mm}$. \\ Habitat. - North Korintji Valley, southwestern Sumatra, $5000 \mathrm{ft}$. \\ altitude. September-October, 1921. C. F. and J. Pratt. One female \\ (type) in coll. B. Preston Clark, received from my friend, Mr. J. J. Joicey.
}

While this form is close to M. sperchius gigas Butler, from northern India, it differs in several important respects. It is darker-colored.

The median abdominal line is heavier. The breadth of the fore wing of $M$. sperchius gigas is $29 \mathrm{~mm}$., so sumatranus is distinctly narrowerwinged. The costal margin is much less strongly curved than in gigas. The distance from that point on the costal margin farthest removed from a straight line drawn directly from the wing base to its apex is $5 \mathrm{~mm}$., while in gigas it is $8 \mathrm{~mm}$. The distal margin is feebly scalloped, contrasting with the strong indentations of gigas. In the fore wing above, the median line, which is straight in gigas, is curved feebly distad. The hind wing above is dark brown, with less of the red tone of gigas. The fore and hind wings beneath are more uniformly brown than in gigas, with a slight tendency to the rufous irroration of gigas. 
Panacra angulata sp. nov.

Al. ant. long., $\sigma^{\nearrow}, 25 \mathrm{~mm}$. Al. ant. lat., $\sigma^{\nearrow}, 10 \mathrm{~mm}$. Marg. ext., $\sigma^{\top}$, $15 \mathrm{~mm}$.

Habitat. - Slopes of Mt. Korintji, southwestern Sumatra, $7500 \mathrm{ft}$. altitude. August-September, 1921. C. J. and F. Pratt. Two males in coll. B. Preston Clark (one the type) given me by my friend, Mr. J. J. Joicey. There are other specimens in Hill Museum, Witley, Surrey, . England.

Antennae brown. Palpus, first segment white, reddish brown along eye, second segment white, reddish brown along eye and at apex. Head and thorax brown. Mesothoracic tegulae deep brown. Legs reddish brown with white scaling. Breast white, heavily irrorated with reddish brown. Abdomen above light brown, with narrow dark brown median stripe. A few blue scales at the segments. Abdomen laterally and beneath, warm reddish brown, with prominent white lateral patches and a broad white median stripe beneath.

Fore wing above: Apex produced, distal margin concave from apex to $\mathrm{R} 1$, thence convex and undulate to hinder angle. Cilia black on veins, yellow between them. Ground tone brown, with darker brown markings. From a point on costal margin $7 \mathrm{~mm}$. from the base a prominent line extends $3 \mathrm{~mm}$. directly toward hinder angle, at that point it is angled sharply, and extends to inner margin, which it reaches $2 \mathrm{~mm}$. from the wing base. Small black stigma, surrounded by light blue scaling. Transverse dark brown median line extends from a point $9 \mathrm{~mm}$. distant from the apex to a point $9 \mathrm{~mm}$. distant from the hinder angle. Small dark cloud costally of this line between R1 and R2. Narrow dark brown postmedian line extends distally of the median one from inner margin to SC5, diverging gradually from the median one, and sharply angled from SC5 to costal margin. A lunulate line, with points distad on the veins, parallels the postmedian line, and between the two is a third line, faint and also lunulate. A faint white apical dot between apex and SC5. A prominent white dash between SC5 and R1, extending obliquely basad from SC5 toward R1. Veins R1 and $\mathrm{R} 2$ are prominently dark brown from distal margin to lunulate postmedian line; veins SC5, R3, M1 and M2 are less prominently so, and for a shorter distance. Area between these veins somewhat darkened, as far as the darkening of the veins extends. Dark brown semilunar area at hinder angle, similar to that in $P$. mydon elegantulus. 
Fore wing beneath: Cilia as on upper side. Ground tone yellow, heavily irrorated with reddish orange. Median dark brown line similar to that on wing above, with dark shade basad of it, the three postmedian lines of the wing above faintly duplicated in reddish orange, as are the heavy brown markings along and between the veins distally. These have the appearance of fingers, with their tips on distal margin.

Hind wing above: Cilia as in fore wing. Distal margin undulate. Ground tone brown. Light red submarginal band extends from anal angle to $\mathrm{R} 2$, broadening to that point; irregular brown line within this area, roughly parallel to distal margin. Blue scaling along distal margin from anal angle to R3.

Hind wing beneath: Ground tone yellow, heavily irrorated with reddish orange. Median basal area light blue, extending along veins SC5, R1 and R2 to distal margin, along R3, M1 and M2, half way to distal margin. This light blue area is continuous between $\mathrm{R} 1$ and $\mathrm{R} 2$, and broadens out to become a submarginal band extending broadly from inner margin to $\mathrm{R} 2$, and then narrowing to hinder angle. Between this submarginal band and distal margin the reddish orange color reappears narrowly. Three dark brown lines, one antemedian, one median, and one postmedian, extend irregularly from inner to anal margin.

A brilliant insect, nearest to $P$. mydon elegantulus Her.-Sch.

\section{Nephele joiceyi sp. nov.}

Al. ant. long., $\sigma^{\top}, 44 \mathrm{~mm}$. Al. ant. lat., $\sigma^{7}, 18 \mathrm{~mm}$. Marg. ext., $\sigma^{\top}$, $24 \mathrm{~mm}$.

Habitat. - Slopes of Mt. Korintji, southwestern Sumatra, $7300 \mathrm{ft}$. altitude, August-September, 1921. Collected by C. F. and J. Pratt, and given to me by my friend, Mr. J. J. Joicey. Two males (one the type) in coll. B. Preston Clark. There are also specimens in Hill Museum, Witley, Surrey, England.

This insect is allied to $N$. didyma Fabr., but is clearly distinct. It is larger.

Coloration similar to that of $N$. didyma. Palpus, breast and lateral line extending from the eye to base of fore wing, more prominent than in $N$. didyma.

Fore wing above: Darker brown than in $N$. didyma, with a prominent 
black line bordering the light-colored distal marginal band. Very noticeable are the shape and relative location of the two silvery spots on the upper side of the fore wing. The dot nearer the costal margin is circular, as in $N$. didyma. The posterior one, however, is on a line drawn vertically from the costal margin through the circular spot, instead of being located more distally, as in N. didyma. The shape of this second spot is roughly triangular, with its base on R3, instead of semilunar as in N. didyma.

Fore wing beneath: The postmedian and the submarginal lines approach so closely to R2 as nearly to touch, the space between the two lines being thus practically a double triangle, with apices on R3. In $N$. didyma these two lines are parallel from R1 to the hinder margin.

Hind wing above: Darker in tone than in N. didyma, shading to black throughout the distal half of the wing.

The black transverse bands on the abdominal tergites are prominent, as are a series of black lateral abdominal dots on sternites 3 to 7 .

\section{Cechenena pollux Boisd., ab. rubrescens forma nova}

A single specimen (a male) of this species in the collection of B. Preston Clark varies so distinctly from the rest of a long series that it deserves mention. It was taken on the slopes of Mt. Korintji, in southwestern Sumatra, August-September, 1921, by C. F. and J. Pratt. The normal green color of this species is replaced throughout by reddish brown. The line on the upper side of the fore wing, extending from wing apex to the median point of the inner margin, is broader than in typical C. pollux. There is greater contrast in color between the transverse lines of the fore wing above, as a whole, and the remainder of the wing. It may be that $C$. pollux shares, but more rarely, the tendency of Xylophanes amadis Stoll in Cramer, which varies normally from green to reddish brown.

The two following new forms were received in exchange from the Bureau of Science, Manila, Philippine Islands. Both are remarkable, and Xylophanes transpacifica marks a new link in this family between the Orient and the Occident. 
Cephonodes banksi sp. nov.

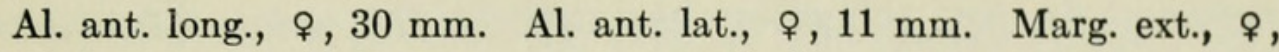
$18 \mathrm{~mm}$.

Habitat. - Baguio, Benguet, Philippine Islands. One female (the type) in coll. B. Preston Clark, taken February 17, 1910, by Mr. J. P. Iddings, and sent to me by Mr. C. S. Banks of Manila, for whom it is named.

This interesting species is allied to $C$. rothschildi Rebel and to $C$. titan Roth. The abdomen of $C$. rothschildi is green and unicolorous above, while that of $C$. titan is black and unicolorous. This form stands midway, with three green segments, a dark red band, and black posterior segments.

Head, thorax, and abdomen above, including segment 3 , greenish yellow (probably faded from green). On abdominal sternite 4 a narrow dark red band. Remaining posterior segments of the abdomen coal-black. Tip of tail yellow as in C. rothschildi, but less markedly so. Palpi uniformly yellow. No white ring around the eye as in C. rothschildi. Breast and legs deep yellow, not orange as in $C$. rothschildi. Abdomen beneath coal-black except at tip, which is yellow.

Wings in all respects similar to those of $C$. rothschildi, except that the distal border of that species is lacking entirely even at the wing tip. The anal border of the hind wing is narrower, and less extended toward the anal angle, than in $C$. rothschildi.

\section{Xylophanes transpacifica sp. nov.}

Al. ant. long., ९ , $43 \mathrm{~mm}$. Al. ant. lat., ๆ , $18 \mathrm{~mm}$. Marg. ext., ๆ, $24 \mathrm{~mm}$.

Habitat. - Manila, Philippine Islands. One female in coll. B. Preston Clark, taken by Mr. W. Schultze, and received by me in exchange from the Bureau of Science at Manila.

This remarkable insect is, so far as I know, the first specimen of the genus Xylophanes, that has been taken outside of the 
Americas. It is closely allied to Xylophanes rufescens Roth., resembling it closely in general appearance and maculation, especially on the fore and hind wings beneath, and less closely so on both wings above. The only female specimen of $X$. rufescens in my collection has exactly the same dimensions, $43 \mathrm{~mm}$., $18 \mathrm{~mm}$. and $24 \mathrm{~mm}$., as this specimen.

Antennae, slender, reddish brown, white toward tip; hook long and gradual. Eye not lashed. Legs yellow, mid tibiae white. Palpus: first segment white irrorated with brown at the base, the rest of segment reddish brown, yellow along the eye; second segment light brown. Eye large. Head, thorax and abdomen above, uniformly reddish brown. Breast and abdomen beneath, yellow laterally. Median area of breast yellow, and of abdomen light yellow irrorated with black. Dark brown lateral side stripe. Cilia of fore wing reddish brown above and beneath. Cilia of hind wing reddish brown above and beneath from SC5 to R3. White between the veins from R3 to anal angle, as in $X$. rufescens.

Fore wing above: Ground tone buff, densely shaded and irrorated with reddish brown, closely resembling $X$. rufescens. Black transverse longitudinal irrorations along submarginal distal area, and for some distance along costal margin from the wing tip. Dark apical mark as in X. rufescens, from which a line extends irregularly to R2. Small dark stigma in a circular buff area.

Fore wing beneath. Basal half brick red. A heavy irregular dark red line extends from a point on the inner margin $10 \mathrm{~mm}$. distant from the hinder angle to a point on the costal margin $16 \mathrm{~mm}$. distant from the wing apex, curving basad as it approaches this point. Another fainter and similar line parallels this distally. A series of prominent black vein dots about $9 \mathrm{~mm}$. distant from the distal margin. A strongly marked brown distal marginal band, lightly irrorated with black, $1 \mathrm{~mm}$. in width at the wing apex, widens to $9 \mathrm{~mm}$. at $\mathrm{R} 2$, where the black vein dot exactly touches its edge, thence it narrows abruptly to a width of $5 \mathrm{~mm}$. on R3, and extends irregularly, broader between the veins, to hinder margin, where it is $2 \mathrm{~mm}$. in width. This band is identical in general form with that of $X$. rufescens. The median area between the distal marginal band and the red basal area is yellow, irrorated with black transverse markings.

Hind wing above. Black basally. Reddish brown distal marginal band, $5 \mathrm{~mm}$. in width along inner margin, narrows gradually to SM2, where it becomes vestigial. Median area light buff across the whole width of the wing, lighter in color anally.

Hind wing beneath. Transverse dark red median line extends from inner margin to M2. Brown distal marginal band similar in area to that on upper side of wing. Remainder of wing area yellow heavily irrorated with reddish brown, except along anal margin, which is lighter in tone. 


\section{Nephele triangulifera Closs.}

I have in my collection the type of this species (Closs., Int. Ent. Zeitschr. 7, p. 317), and it varies in no respect from a series of Nephele comma, f. comma Hopffer. It cannot therefore be regarded as a valid form, and the name should be relegated to the synonymy of $N$. comma, f. comma Hopffer.

Gurelca chaochauensis B. P. Clark, was described in the Proceedings of the New England Zoölogical Club, Vol. VIII, p. 13, Jan. 25, 1922, from a single male from Chaochau, received from Dr. R. Luck and B. Gehlen. A long series of this form had been bred by Mr. Rudolf Mell, and the form was subsequently described by him as Micracosmeryx macroglossoides. I did not recognize the species as generically distinct from Gurelca, which it certainly is. The specific name given by me, however, has priority, and the form should be known as Micracosmeryx chaochauensis B. P. Clark. 


\section{$2 \mathrm{BHL}$ Biodiversity Heritage Library}

Clark, Benjamin Preston. 1923. "Thirty-three new Sphingidae." Proceedings of the New England

Zoo

logical Club 8, 47-77. https://doi.org/10.5962/bhl.part.4001.

View This Item Online: https://www.biodiversitylibrary.org/item/42087

DOI: https://doi.org/10.5962/bhl.part.4001

Permalink: https://www.biodiversitylibrary.org/partpdf/4001

\section{Holding Institution}

American Museum of Natural History Library

\section{Sponsored by}

Biodiversity Heritage Library

\section{Copyright \& Reuse}

Copyright Status: NOT_IN_COPYRIGHT

This document was created from content at the Biodiversity Heritage Library, the world's largest open access digital library for biodiversity literature and archives. Visit BHL at https://www.biodiversitylibrary.org. 